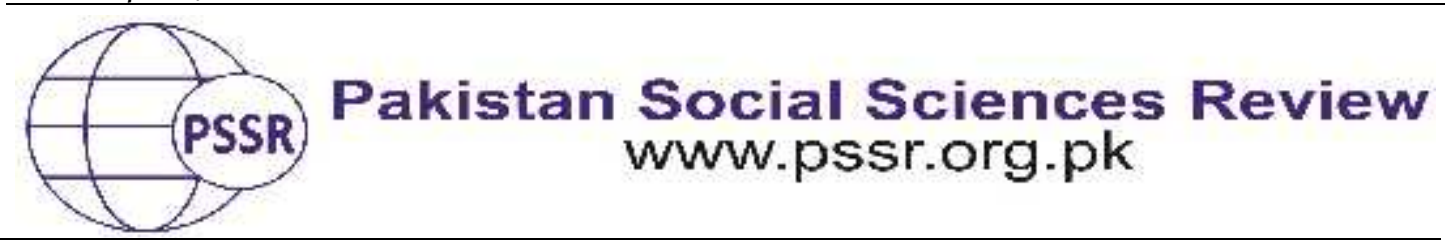

RESEARCH PAPER

\title{
Forensic DNA Profiling and Criminal Justice System in Pakistan: An Analysis
}

Shabana Kouser Jatoi* ${ }^{1}$ Prof. Dr. Raana Khan ${ }^{2}$ Muhammad Nouman Jatoi ${ }^{3}$

1. Ph.D Scholar, Dada Bhoye Institute of Higher Education, Karachi, Sindh, Pakistan

2. Professor, Dada Bhoye Institute of Higher Education, Karachi, Sindh, Pakistan

3. Visiting Faculty Member, Institute of Law University of Sindh Jamshoro, Sindh, Pakistan

\begin{tabular}{|c|c|}
\hline PAPER INFO & ABSTRACT \\
\hline $\begin{array}{l}\text { Received: } \\
\text { March 06, } 2021 \\
\text { Accepted: } \\
\text { May 30, } 2021 \\
\text { Online: } \\
\text { June 05, } 2021\end{array}$ & $\begin{array}{l}\text { The article in hand is written to highlight the importance of } \\
\text { DNA profiling in criminal justice system and need of legislation } \\
\text { with reference to Pakistan. In Pakistani criminal justice } \\
\text { system entire burden of investigation is upon police and } \\
\text { other investigation agencies, which is compelling in nature }\end{array}$ \\
\hline $\begin{array}{l}\text { Keywords: } \\
\text { Admissibility of } \\
\text { DNA, } \\
\text { Court of Law } \\
\text { DNA Profiling, } \\
\text { Forensic, } \\
\text { Investigation, } \\
\text { Paternity Cases, } \\
\text { Secondary } \\
\text { Evidence, } \\
\text { Sexual Assault }\end{array}$ & $\begin{array}{l}\text { for investigator to present him stock witness rather than } \\
\text { relying on scientific evidence, and utilize all other resources } \\
\text { of illegitimate ways to make any case strong. Sindhi society } \\
\text { is heterogeneous and illiteracy is a big problem. Honest eye } \\
\text { witnesses are usually unwilling to record their statement } \\
\text { and even if they do, their statement loses its reliability } \\
\text { during the encounter of extreme cross examinations and re- } \\
\text { examination. The poor rate of conviction destroys the } \\
\text { confidence of the public in the criminal justice system. } \\
\text { Opinion of senior legal practitioners is obtained and a }\end{array}$ \\
\hline $\begin{array}{l}\text { *Corresponding } \\
\text { Author }\end{array}$ & $\begin{array}{l}\text { detalled case study is also conducted in this regard and it } \\
\text { is observed that no one can deny the importance of DNA } \\
\text { profiling in present scenario. This is what is needed now } \\
\text { that Laboratories conducting DNA profiling must be } \\
\text { upgraded and increases in numbers in all over the country } \\
\text { and DNA data base is start developing to reduce crime } \\
\text { rate in Pakistan. }\end{array}$ \\
\hline
\end{tabular}

\section{Introduction}

Human body is composed of countless cells, each one of which carries a complete set of chromosomes. It's an unique structure of biological material which found in each single cell of living organism and in human body. DNA stand for Deoxyribonucleic Acid self-replicating material constituted of chromosomes. It is commonly known as genetic material, which contains a unique genetic code for every person. It is much like an individual's own personal bar code or the blue print of life. Everyone has unique DNA pattern except 
identical twins or monozygotic twins, because they come forth division of single fertilized egg.

- The structure of all living organisms DNA chemically is the same.

- The human DNA only differentiated from animals DNA by its sequence and order of base pairs.

- Everyone could be identified solely by using sequence of their base pairs.

- In DNA millions of pairs are present with a task of any kind which is very time consuming.

- Scientist use shorter method instead of longer, due to repeating designs in DNA.

- These patterns do not, however, give an individual "fingerprint,"

- Experts can decide whether two DNA samples are taken from the single individual, his relatives, or non-related people.

\section{Reasons of Calling DNA as Finger Print}

D.N.A profiling is based on very different principles than traditional finger printing methods; it is to some extent unfortunate that the term "finger printing" has been associated with science of D.N.A testing because of the following reasons:

a) D.N.A traditionally referred to R.F.L.P: While this term has traditionally only referred to R.F.L.P, but some commentators unfamiliar with the science and technology group all D.N.A testing methods, including P.C.R applied to specific genetic loci within the term.

b) Level of Reliability: The term "D.N.A finger printing" is also disfavored because of its tendency to create unsubstantiated beliefs and expectations in the mind of judge's ad jurors. Because D.N.A profiling has not reached a level of reliability comparable to that of finger printing, judges may unfairly draw inference against a defendant based on D.N.A evidence under the influence of the term "D.N.A finger printing".

c) Availability of Sample's from Crime Scene: From crime scene always investigation officer commonly take finger prints, but usually they collect D.N.A samples on a far less constant basis. This inconsistency in collection does not result of non-availability of D.N.A sample at the crime scene, as criminals and especially rapists, almost always leave behind D.N.A samples ad only the reason is ignorance and lack of availability of trained forensic technicians with investigators. 


\section{Samples of Biological materials used for DNA profiling}

- Human Blood

- Hairs and nails

- Saliva

- Semen

- Cells taken from tissues of human body

- DNA samples are collected from vaginal cells which may be come out of a condom during sexual inter course.

\section{Making Process of DNA Slide}

- DNA testing is a scientific procedure performed in laboratory by following six steps:

- Stage 1: Separation of DNA.

- Stage 2: Cutting, sizing, and sorting.

- Restriction enzymes(special enzyme)are used to cut the DNA at specific places

- Stage3: Separation of fragments is based on size using process called "gel Electrophoresis".

- Stage 4: Fragments of DNA are injected in to wells and an electric current is applied along the gel.

- 5: DNA fingerprint.

The absolute DNA profiling report is built by using quite a lot of investigations (5-10 or more) instantaneously

\section{Literature Review}

Punjab Forensic science Act was established in 2007 having 14 different well equipped forensic laboratories include DNA and serology, latent fingerprints, narcotics, polygraph, toxicology, trace chemistry, computer forensic, questioned documents and different other investigation. National police Bureau, Ministry of interior and Govt. of Pakistan collectively launched a project with name of National Forensic science Agency. The agency was formed to provide all necessary forensic services, guidance training and assistance to Law Enforcement Agencies(LEAS), Government Departments and Forensic bodies. To meet the task of Crime detection Forensic science Laboratories has been established and facilities improved in Pakistan and also training is provided to law enforcement agencies for enhancement of capacity and equipment are provided. Thus in this way we can help building public trust in the criminal justice system. Forensic sciences are playing a key role in criminal justice system framework everywhere in the world. Forensic in our country Pakistan, overlooked for quite a while. The progressing fear mongering 
surrendered a wake call to the foundation and untiring endeavors were made for the setting up and legitimate working of the scientific lab to support criminal examinations Since 2001, specialists have been patching up legal science framework the nation over to help wrongdoing examination. The National Forensic Science Agency (NFSA) was affirmed by the Executive Committee of the National Economic Council (ECNEC) as a self-governing body in 2002 having branches of wrongdoing scene Investigation, follow science, addressed archives and computerized crime scene investigation (National Forensic Science Agency, n.d. In Sindh area, Sindh Forensic Science Agency act was passed on August, 2017 yet so far no research center has been set up. DNA testing office accessible in Jamshoro, Sindh which gives look into just as legal DNA testing. Other than this, legislature of Sindh is putting forth attempts for foundation of Forensic DNA testing lab in Karachi University. Khyber Pakhtunkhwa police has set up Forensic Science Laboratory and Institute of Forensic Science in Peshawar on December, 2017 to give primer scientific offices and to overcome any issues between measurable mindfulness and criminal examination rehearses. In Balochistan region of Punjab, a demonstration was passed for the foundation of Balochistan Forensic Science Agency on August, 2015 however no criminological office has yet been set up. At present, NFSA and PFSA are giving numerous significant examination leads in different repulsive violations. Presently overall population and legal executive of Pakistan are depending intensely on Forensic confirmations in preliminary cases and deciding. As legal science fame increments in the nation so does the build-up. An ever increasing number of cases are being gotten every day which is causing delay for the situation preparing and at last deferred equity. There is a need to expand the limit and number of the Forensic research centers the nation over as ebb and flow office is inadequate remembering the huge number of cases originating from large populace of Pakistan (Population Welfare Department, As populace of Punjab territory of Pakistan is 110 million, a solitary scientific research center at commonplace level can't satisfy the prerequisite of this area. There is a desperate need to build up and reinforce the framework of the criminological research facilities in Sindh, Khyber Pakhtunkha and Bolochistan territory of Pakistan.

\section{Admissibility of DNA Testing}

- DNA evidence is admissible under provision of Art 164 \&59 Qanoon-eShahadat Ord ( QSO 1984)

- Article 59 of QSO read as: 


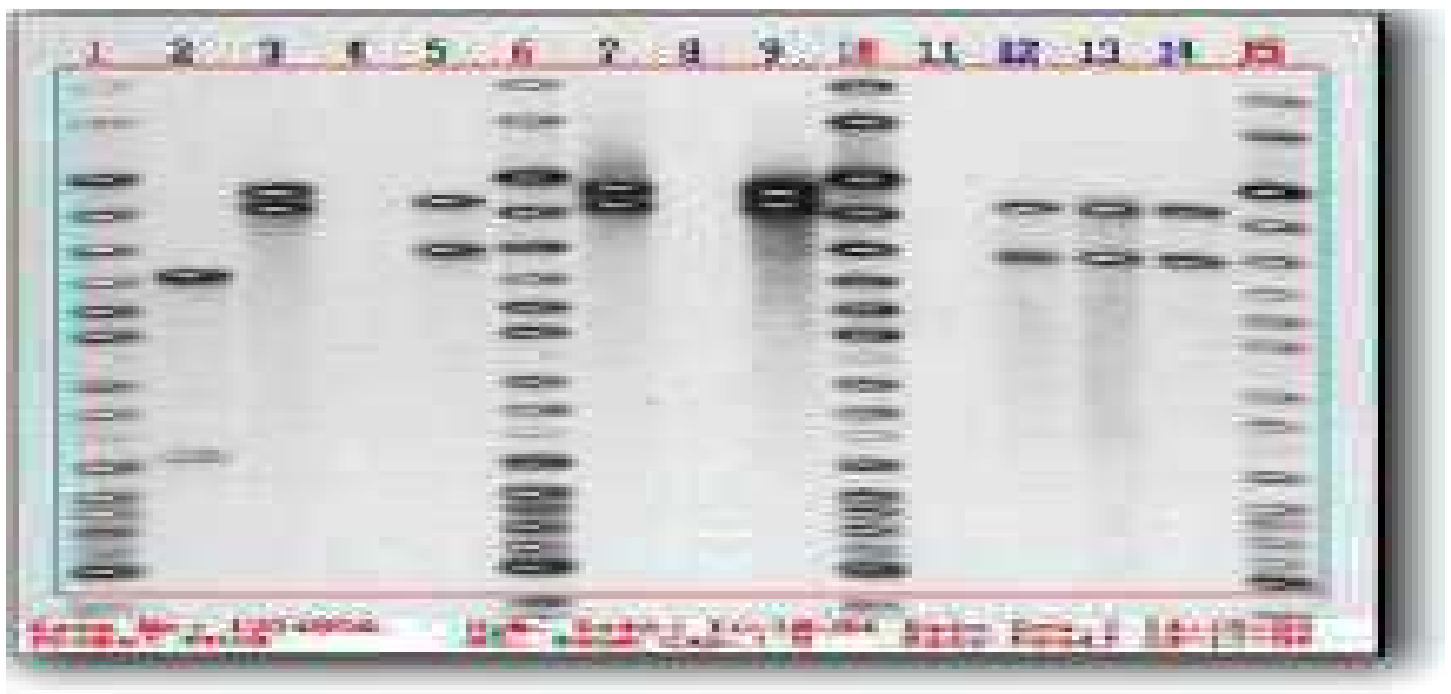

\section{Fig.No.1 DNA Slide after Preparation for Matching by Investigation Agency or Police in Rape Cases}

Article 59 provides the admissibility of opinion of expert of any field of science and arts in any case and Article164of QSO provides that evidence become in existence due to modern devices could be admissible if its integrity is proven and not questioned by anyone.

In absence of particular frame work that specifically deals with DNA, courts in Pakistan have to manoeuvre/plan to improve the available legal framework. DNA testing is valued in the perspective of Art 164\& 59Qanoon-eShahadatOrder1984('QSO'). In legal frame work presently available, the Serologist who performs testing to scrutinize DNA evidence is considered as an expert whose opinion is acceptable before court. It is admissible and considered like medico legal opinion, in this contest it develop an impression that it is also a type of evidence related to MLO, and that expert of DNA profiling is like a doctor. It's very important to remark here that there is a big difference between these two evidences is that the Medical evidence does not provided for the such type of condition where the identity of offender is to be traced and DNA evidence performs that function and it traces identity of culprit with greatest degree of accuracy hence forth impression that it is also another type of medico legal evidence is misconceived.

Jurisprudence of Pakistani courts is controversial when it comes to admissibility of DNA as evidence. It is dealt on secondary footings and needs corroboration, however the courts have shown their reluctance to allow DNA tests in cases of legitimacy of children besides these three further limitations are put on DNA evidence and these are: 
1) In cases of Zina (EoH) Ordinance (VII 1979) Ss. 10, 11 \& 19 it is not admissible as provisions of Zina in Hudd cases has its own standard of proof (2013 PCr.LJ 772).

2) It must be conducted from notified laboratory

3) It shall be taken voluntarily; it shall not infringe individual's right to liberty.

Hence the crux of matter has been bifurcated into streams. One deals with admissibility of DNA under case laws and other deals with limitations on DNA evidence. It is pertinent to analysis theses streams separately in order to reach at the core of matter.

No other type of evidence is capable of producing so much information about the individual whose biological sample is analyzed. It allows both the ambiguous and definite proof of identity of the offender from traces of biotic material found at the place of incident and the acquittal of innocent suspects. DNA is an indispensable weapon in fighting against crime.

\section{Case Law on Admissibility of DNA Evidence}

DNA evidence is admissible to the extent of sexual offences. It is dealt on secondary footings and needs corroboration

Case Law: 2013 SCMR 2003:-It is held by Honourable Supreme Court of Pakistan that:

"It is should be noted that to determine their liability or truth of allegation of any fact administration of DNA test is not new. In the beginning DNA was not considered so trustworthy, as a result, Courts frequently excluded or omit it from the evidence and conviction was not awarded on its base" Pakistani courts are also considering the DNA profiling results on the time of convicting accused; however, DNA testing could not be considered as definite prove and no corroboration is required from oral evidences"

In case of Mohammad Shahid Shil v/s The State \& another(PLD 2010 FSC 215), the Honourable court held:-

"During investigation of criminal cases the identification of culprit is a primary element of importance "In most of rape cases about sexual assault direct evidence could not available, nevertheless if presumption could be taken place that it was a result of unlawful act, then offender could surely and easily be recognized by using methods of advanced technology in investigation"

"Pakistani prosecution must take notice and should use the latest existing technology to find and locate the real culprit and also time will be 
secured. DNA profiling is an effective clincher". As discussed earlier DNA evidence needs corroboration. In case zulfiqar ali v/s the state(2010 YLR 847), The culprit was convicted when Chemical examiners report and DNA report lent corroboration.

In case Mst Zohra bibi v/s The state(2013 pcr.lj 772), the controversy came before Federal Shariat court where semen grouping as well as DNA test of accused was not conducted. The Honourable court held:-“In absence of semen grouping as well as DNA test, no accused could be held guilty of committing the offence of zina with mst. Saida Rashid (The victim)"

In case Muhammad Ashfaq v/s The state(2014 pcr.lj 1531), The controversy came before Lahore High court where the DNA test of accused was not conducted, that court held that" In our consider at view benefit of this omission shall go to the accused consequently the accused was acquitted of the charge.

"DNA evidence is practically a definite evidence of one's individuality", the said view was held by Honourable Sindh high court in case Muhammad Aslam Khan v/s The state(2008 Pcr.LJ 1623).

\section{Limitations on DNA Evidence}

\section{Paternity/Legitimacy of Child Cases}

When cases about legitimacy of child comes before the courts the court resort to presumption under article 128 of QSO in absence of direct evidence.

Case law: PLD 2015 SC 327 (Ghazala Tehseen Zohra V/S Mehar Ghulam Dastgir Jaan \& another):-Honourable Supreme court of Pakistan held in above matter that:"In the Art.128 Qanoon-e-Shahadat it is provided in such language which is protecting for collective consistency and community values. This appears to be a foundation for specifying positively that birth of child during marriage and before completion of two years if mother remain unmarried shall be definite proof of legitimacy. Or else it could not be possible that framer of classic Islamic jurisprudence or legislature of Qanoon-eshahadat order 1984 could be unaware of scientific fact that period of gestation human foetus could not be more than 12 months in any condition. Then purpose of extending period for legitimacy to two years actually in spite of this fact legislative intent only was to avoiding controversy in matter of paternity".

This provision of Qanoon-e-shadat U/A 2(9) has to be reconciled with clause(a) of article 128 QSO. The specification in article128 is that the birth of child with in period stipulated definite proof of legitimacy of child. Once the relevant facts as to beginning and dissolution of marriage and the birth of 
child within period projected under Art.128 is proved then Court could not allow to adduce evidence for disproving the legitimacy of child born before completion of two years."

The crux of above jurisprudence of apex court is that DNA tests will not be allowed if the relevant facts as to commencing of period after dissolution of marriage and birth of child within period projected in article 128 is proved. In case Mohammad Arshad v/s sughran bibi and 2 others (PLD 2008 LAH 302), The honourable Lahore high court has held: "The allegation by a husband or his act of rejecting child born out of marriage is to be verified through solid and reliable evidence. Legitimacy of child born out of legalised marriage always carried presupposition of truth in its favour and mere simple denial can never take away the child legitimacy status, in majority of cases, according to Muhammdan law "child follows the bed" is acknowledged to be an issue of his parents without acknowledgement or affirmation on the part of father, the child follows the bed(firash)"

In above case the court declined request for DNA test and adhered strictly to principle "Child follows the bed"

The Honourable Lahore High court has held in case Khizar hayat v/s Additional and district judge kabirwala \& 2 others(PLD 2010 LAH 422):"As per article 128 of Qanoon-e-shadat 1984, the birth during marriage is conclusive proof of legitimacy" "DNA test is not to be ordered to be conducted as commonly in those type of cases in which the father refuses to acknowledge his offspring which born in result of lawful wedlock, for the reasons that otherwise the presumption under Article 117,118,119,128 of QSO that a child during continuation of legal wedlock and before completion of two years of marriage dissolution, provided that if lady stayed unmarried throughout this period, should be definite proof of legitimacy of child that man unless man denies the act, In this case the petitioner himself has admitted that he divorced respondent no.2 in the year1998 where as the respondent no.3 was born in the year1997. This fact by itself indicated that respondent no.3 was born during the subsistence of valid Nikah. Then under Art.128 QSO it could be safely presumed that respondent no.3 is the child of petitioner"

"it has been observed by this court that it has become a common practice that when a relation between parties becomes strained after marriage and even extreme hatred is developed between spouses and same is dissolved, the parties do not spare each other even to the extent that often father refuses to acknowledge the child for the reason either to avoid maintenance or to deprive child from inheritance of in case of his second marriage at the insistence of his second wife or pressure of elders of family and this trend is not only damaging but is also dangerous for the society and in such situation request for DNA is not proper" 
"While science has been developed in the modern times but unluckily at the same time it has not reached the level of accuracy, capability of person connected with these tests and their impartiality in our society and prevalent system as it has been applied in the developed societies like USA and Europe, either due to lack of skilful person, apparatuses to conduct this test and human error in judgment in conducting of this test cannot be ruled out in our system. If due to negligence in conducting tests wilfully or due to some pressure, it results in a disaster not only to affect but also by and large for the entire society. If due to any of above mentioned reasons a wrong result is obtained than the life of child would become miserable for the non-fault on is fault and he would never come out of this dilemma and there would be no place for him in the society and will be called as an illegitimate child".

The apex court in case sharafat ali ashraf $\mathrm{v} / \mathrm{s}$ additional district judge Bhawalpur \& 3 others(2008 SCMR 170) declined to allow DNA test and held:-"It is the rule of substantive law that a child born throughout the period of legal wedlock \& not before than completion of at least six lunar months from the day of such wedlock or during the period of two years after the dissolution of the marriage shall be the definite proof of legitimacy of child of spouses provided the mother remained unmarried". The Honourable Lahore high court in case Mohammad Azhar v/s The state(PLD 2005 LAH 589)has admitted that DNA test helps in establishing the legitimacy of child but has put another limitation on DNA evidence, The Honourable court held:- "If husband imposed accusation of zina against his wife than the DNA test can play a key role as evidence for establishing that accusation against that lady and could be utilized as justification for taking of oath as ordained by surah Al-Noor which results to penalty of nullifying marriage. An interesting thing to be noted here is that above authority catered for solving case Khadam hussian v/s state(2011 Pcr.LJ 1443) and mst. sarwar mai v/s judge family court muzzafar garh \& others(2010 YLR 1234) but same authority was over ruled by Federal shariat court in Muhammad shahid sahil v/s the state(PLD 2010 FSC 215).

The Honourable Federal Shariat court held: "I am conscious of the fact that in the case of Mohammad Azharv/s The STATE, the learned Justice of Lahore high court has found that the usefulness and evidentiary value of DNA may further help in establishing the effectiveness and evidentiary value of DNA test may further help in establishing the legitimacy of child and for other purposes but not in Hudood cases of Zina because it has according to Islamic provisions its own standard of proof as:

(a) Under Hudood law relating to Zina, convictions are generally recorded not under section 8 of Zina (Hudood ordinance1979) but convictions are in variable recorded under section 10 which deals with zina liable to Taa'zir 
(b) After all method of semen grouping or chemical analysis to detect semen or blood of human origin in cases falling under criminal jurisdiction is the contribution of modern scientific age which is being employed by the courts including Federal Shariat court.

(c) The Holy Quran and Sunnah has no where prohibit from taking assistance of scientific or analytical method for determining the truth.

The authority of Federal Shariat court stands on higher pedestal than authority of High court therefore Case Law Mohammad Azhar v/s State (PLD 2005 LAH 589), Khadim hussian v/s state(2011 Pcrlj 1443) and Mst.sarwar mai v/s Judge Family Court Muzzafargarh \& others (2010 YLR 1234) are per in curiae and has no legal validity.

\section{DNA test must be conducted from notified Laboratory}

The third limitation on admissibility of DNA evidence as imposed by Honourable courts is that it must be from notified laboratory. The controversy came before Peshawer high court where DNA test was not conducted from notified laboratory, The Honourable court held:-“So far DNA test is concerned, it can safely be held that, being not conducted from notified laboratory, is not admissible in evidence not could be a base for conviction in a case of capital punishment" (PLD 2013 Peshawer 78).

DNA test shall be taken voluntarily, it shall not infringe individual's right to liberty

The fourth limitation upon DNA evidence is put by Islamabad High court, The Honourable High court has held in case Malik Muhammad Rafique v/s Mst. Tanveer jahan \& another(PLD 2015 Islamabad 30) "In this cases challenge was to the paternity of a person, ordering in routine, compelling litigants to go through a DNA test can have serious consequences, beside intervention with personal liberty. It seldom interferes by ordering a DNA test except under exceptional circumstances. It is also significant to note that it is not enough to simply make out a case, rather a strong prima facie case must be established before court could exercise its powers having the effect of interfering with personal liberty. Allowing an opportunity to a fish a cause to create doubts regarding the paternity of a person can neither been courage nor taken lightly"

"It is therefore obvious that neither can blood samples be taken nor a DNA test is conducted in a routine, unless a person whose paternity has been challenged expressly gives his/her consent".

The Honourable Supreme court of Pakistan has also held as a view in case Salman Akram raja v/s Govt. of Punjab through chief secretary \& others (2013 SCMR 203) "It is well settled law that victims consent is very important 
and forcibly no one could be subject to DNA and other medical testing for purpose of any criminal trail and prosecution because it would be considered as infringement of right of personal liberty and privacy of that person."

\section{Paternity Cases}

D.N.A testing has been used extensively for paternity testing as well as criminal investigation. D.N.A profiling has particular application to the criminal law because of the possibility that it offers of determining whether blood or semen deposits located at scene of a crime come from a person suspected of having committed the crime. D.N.A technology is especially useful in investigations into murder or sexual offences. Whenever an assailant is injured or leaves any form of body sample at the scene of crime (such as hair roots, saliva, blood, remains, etc) the D.N.A profile has the potential to identify the person from his or her own deposit of biological material. It can also exculpate the suspect. D.N.A technology provides the possibility of identifying victims of anonymous crimes such as hit and run accidents.

\section{Limitations to admissibility of DNA evidence in Pakistani courts}

No particular legal framework and forensic law is available in Pakistan, that deals with DNA evidence or other forensic evidence, and hence the courts have to manoeuvre while remaining within legal frame work yet available but $\mathrm{u} / \mathrm{s}-156(\mathrm{D})$ of Cr.P.C. DNA test has become mandatory in investigation of Zina and murder case. The DNA reports are not admissible u/s 510 of Cr.P.C.(2016 SCMR 274) DNA evidence is evaluated in the context of Article-59 and Article-164 of the QSO. Under the prevailing legal framework, DNA evidence is regarded as equal to an expert opinion, and is considered as corroboratory evidence. Courts in criminal cases consider DNA test at the time of awarding conviction but it needs corroboration as stated in Azam Khan $v / s$ Mujahid Khan(2016 SCMR 274), that DNA has merely corroboratory value and cannot be regarded as primary evidence. In courts presently if DNA assessed from this perspective exclusively, then we might fully not benefitted from its usage. In Sikandar v/s The State,(2006-SCMR-1786) it was held that the main difference among DNA and medical opinion is that medical opinion does not identify the offenders where as DNA profiling do it with accuracy of high degree.

On the basis of saying of Holy Prophet (P.B.U.H), a child is attributed to a person in whose wedlock he/she is born(PLD 1975 SC 624). When the cases as to legitimacy of child comes before the courts, the court does not allow DNA test to be conducted but it resort to presumption $\mathrm{u} / \mathrm{A}-128$ of QSO in absence of direct evidence. In Ghazala Tehsin $v / S$ Mehr Ghulam Khan,(PLD2015-SC-327) the court considered DNA profiling with observation that Article128 is embedded in language which is shielding social consistency and values of citizens. It means that a child who is born within two-years after the 
dissolution of marriage between his parents (mother remaining un-married) shall constitute conclusive proof of his legitimacy.

\section{Sexual Offences}

In Salman Akram v/s Government of Punjab,(2013 SCMR 203) the SC directed that DNA tests be conducted in all sexual offences $\mathrm{u} / \mathrm{A}-59$ and 164 of QSO, because it helps in identifying real culprits with a extraordinary degree of sureness/accuracy, hence by utilising DNA profiling in cases Judge will be in good position to reach at a decision by which real offender would be convicted, probable suspects would be excluded and innocent person would be acquitted. In Umar Taj $v / s$ The State,(Petition no.2648-p/2017) the court held that $\mathrm{u} / \mathrm{s}-164(\mathrm{~B})$ of Cr.P.C which was made into Criminal Law Act 2016, is related to conducting of DNA tests of both shall be applicable to offenses u/s-376 of P.P.C and it was also up held in Zainab's case. In Supreme Court accused was convicted in sodomy case on basis of DNA test(PLD 2005 SC 484).

In Pakistan there are only two notified laboratories

1. Forensic Laboratory situated at Lahore

2. Diagnostic and research of Liaquat Medical University laboratory Jamshoro

Some prominent cases have been explained with the assistance of legal examination apparatus are the Marriot Hotel impact in 2008, Lal Masjid activity in Islamabad, suicide impact on a political assembly in Karachi, Kasur occurrence and diverse others. Based on their interest and to diminish the NFSA trouble, the Punjab region was passed the PFSA Act on October 2007 to set up well-prepared research centre in Punjab to improve and guarantee the standard examination.

A gigantic measure of cases are pending in our police division and the police work force are new to Personal Protective Equipment and not prepared to make sure about the wrongdoing scene and to gather the physical proof without sullying. Aside from Punjab, Sindh, Khyber Pakhtunkhwa and Balochistan have not all around created and good scientific examination offices and capable chain of guardianship. The alcohol argument against Pakistan People's Party leader Sharjeel Memon is the paradigm of the investigation team and forensic examination group's untrustworthiness.

International Case of Saddam Hussain Fast track D.N.A test were used to confirm the identity of deposed Iraqi dictator Saddam Hussain, after his capture by U.S forces. Saddam Hussain was discovered in a small underground chamber near a shack in the village of Ad Dawr south of his home town tikrit. At that time U.S president was George Bush and he was informed that a man thought to be Saddam had been captured, but it was 
not confirmed yet. When Saddam Hussain was arrested it was not confirmed that he is really the actual one or not. Major general roy odierno who was the commander of $4^{\text {th }}$ infantry division that caught Saddam Hussain said in an interview that the former dictator confirmed his identity when asked "I am Saddam Hussain, I am the president of Iraq and I am waiting to negotiate (report by MSNBC). They said that Saddam Hussain had a small tattoo on one hand, believed to indicate Hussain. However D.N.A test were carried out to prove the prisoner was not one of the many "body double's" of the former dictator.

\section{Material and Methods}

This topic is studied with perspective of law and need of legislation.

In this study Qualitative Research methodology is used and results are given in descriptive method. By application and type it is pure research method and it is qualitative method and idiosyncratic and, especially in the courts and in practice, the outcomes are often limited to the specific facts of the case. But presently along with case study opinion senior legal practitioners is also obtained which is up to some extent is quantitative in nature so I can easily say that mixed methodology is used in this research. Survey was conducted by Questionnaire method.

\section{Results and Discussion}

In this research survey was conducted by filling questionnaire from Advocates, Judicial officers and Doctors.

Table 1

\begin{tabular}{clcccc}
\hline S. NO & \multicolumn{1}{c}{ Questions } & Yes & No & May Be & $\begin{array}{c}\text { I Don't } \\
\text { Know }\end{array}$ \\
\hline O1 & $\begin{array}{l}\text { Do you think that field DNA } \\
\text { evidence is useful in the Criminal } \\
\text { investigation? }\end{array}$ & $81.25 \%$ & $12.5 \%$ & $0 \%$ & $6.25 \%$ \\
\hline 02 & $\begin{array}{l}\text { Is DNA is a quick evidence in order } \\
\text { to decide any case civil or criminal? }\end{array}$ & $50 \%$ & $37.5 \%$ & $12.25 \%$ & $0 \%$ \\
\hline 03 & $\begin{array}{l}\text { Is DNA evidence is a substantial } \\
\text { evidence? }\end{array}$ & $75 \%$ & $12.5 \%$ & $18.5 \%$ & $0 \%$ \\
\hline 04 & $\begin{array}{l}\text { DNA provides enough evidence to } \\
\text { convict an accused person and release } \\
\text { innocent. }\end{array}$ & $50 \%$ & $37.5 \%$ & $0 \%$ & $12.25 \% 1$ \\
\hline 05 & $\begin{array}{l}\text { "DNA evidence must be used and } \\
\text { relied on courts". Do you agree? }\end{array}$ & $100 \%$ & $0 \%$ & $0 \%$ & $0 \%$ \\
\hline 06 & $\begin{array}{l}\text { Do you think that DNA evidence is } \\
\text { not allowed in Islamic law? }\end{array}$ & $12.5 \%$ & $87.5 \%$ & $0 \%$ & $0 \%$ \\
\hline 07 & $\begin{array}{l}\text { Is DNA evidence is helpful to } \\
\text { determine the legitimacy of child? }\end{array}$ & $87.5 \%$ & $12.5 \%$ & $0 \%$ & $0 \%$ \\
\hline 08 & $\begin{array}{l}\text { There should be more DNA centers } \\
\text { and laboratories in Pakistan. }\end{array}$ & $81.25 \%$ & $18.75 \%$ & $0 \%$ & $0 \%$ \\
\hline
\end{tabular}




\begin{tabular}{clcccc}
\hline 09 & $\begin{array}{l}\text { Do you think that DNA evidence is } \\
\text { helpful to solve cold(old) cases? }\end{array}$ & $81.25 \%$ & $18.75 \%$ & $0 \%$ & $0 \%$ \\
\hline $\begin{array}{l}\text { Is DNA evidence is useful to provide } \\
\text { justice and also to enhance efficiency } \\
\text { of criminal justice system? }\end{array}$ & $87.5 \%$ & $12.25 \%$ & $0 \%$ & $0 \%$ \\
\hline RESULT:MEAN & 80.2 & 20 & 15 \\
\hline
\end{tabular}

\section{Discussion}

Majority of respondents agreed with its importance and suggested that number of labs should be increased and legislation about the SOP's of sending sample for DNA should be framed and deep rooted legislation is required.

\section{Conclusion}

It is thus concluded that evidence of DNA profiling is admissible as evidence but a conviction cannot solely be based on it, for convicting the culprit corroboration is needed from other pieces of evidence. As regards the limitations on its admissibility, it is well settled that:

1) It must be from notified laboratory.

2) There must be consent of victim whose DNA is to be tested or who demands that DNA of culprit shall be tested, coercion if any would amount to violation of personal liberty, it must not be lost out of sight that consent of culprit is not required.

3) In cases as to legitimacy of children Courts are reluctant to allow DNA evidence. Where child born during legal wedlock and father refuse to own his child DNA profiling can play a key role(2012 YLR 1752).

4) It is also helpful in identification of dismembered and putrefied bodies. But in present system it not used for such cases and investigator use old methods.

5) It is helpful in identification of accused in suicide bombing cases too. Now days it is practiced but not up to such level which is required by present situation.

6) It is also helpful in such cases when husband accused his wife for adultery(2008 SCMR 1707).

DNA evidence is conclusive evidence for identification of accused where the accused uses different identities in order to conceal his real identity. In Province of Sindh in respect of Forensic testing there is a need of proper legislation to describe boundaries and procedure for Forensic testing. In respect of other Provinces it is very important to mention that there must be 
the investigation system is modernised and improved according to need of time.

\section{Recommendations}

1. With modernism of crimes, law should also be modernized.

2. Law with respect to DNA and its usage and its validity must be made by the legislative authorities of the country.

3. DNA is helpful in not only criminal cases but also in civil cases, it provide a lot of help by determining legitimacy of child specially in cases of inheritance, its usage must not be declared to be in contradiction with Islamic injunctions.

4. Number of designated laboratory should be increased for speedier investigation and trail.

5. Trained forensic technicians expert in maintaining integrity and collection of DNA detecting material and other forensic evidence from crime scene should be part of investigation team.

6. National DNA database centrally connected should be established to reduce crime rate.[35]

7. According to Ella Lopez; “One man's trash is a Forensic Scientist's treasure." Therefore it should be collected experts wisely. 


\section{References}

(2002, P.cr.L.J.1541

2006-SCMR-1786

2008 SCMR 1707

2008 SCMR 1707

2010 YLR 1234 (Lah).

2011 PCrLJ 1443 (FSC)

2011 PCrLJ 1443 (FSC).

2012 PCrLJ 816 (FSC).

2012 YLR 1752

2012 YLR 652 (FSC).

2012 YLR 847 (FSC).

2013 MLD 1790 (Lah).

2013 PCrLJ 733 (Lah).

2013 PCrLJ 772 (FSC).

2013-SCMR-203

2014 PCrLJ 1531 (Lah).

2014 PCrLJ 599 (Lah).

2016 SCMR 274

2016-SCMR-274

Pakistan Criminal Procedure Code, 1898-2, quoted in by M. Mahmood: Major Acts2004 ed, Part-v. Chapter xiv, p.297.

PetitionNo.2648-P/2017

PLD 2010 FSC 215.

PLD 2010 Lah 422. 
PLD 2011 SC 554.

PLD 2013 Pesh 78.

PLD 2015 SC 327.

PLD-1975-SC-624

PLD-2013-Peshawar-78

PLD-2015 Islamabad 30

Section 164-a and 164-b of Cr.P.C

See Article 128 of QSO. 